\title{
Basilar impression of the skull in patients with adult coeliac disease and after gastric surgery
}

\author{
L. J. HURWITZ1 ${ }^{1}$ AND N. K. BANERJI \\ From the Department of Neurology, Royal Victoria Hospital, Belfast
}

SUMMARY Chamberlain's, McGregor's and Bull's angle measurements for basilar impression of the skull were made on 22 adult patients with idiopathic steatorrhoea (probable gluten enteropathy), 24 patients who had had previous gastric surgery, and 48 control subjects. For each of the three measurements a value greater than the mean plus two standard deviations was taken as the upper limit of normal. In seven patients with adult steatorrhoea all three measurements were abnormal suggesting basilar impression, while basilar impression was probable in only one patient who had gastric surgery. The trend towards abnormal measurements was significant in the steatorrhoea patients but not in those who had gastric surgery. Basilar impression also was present in patients who did not have rickets or present evidence of osteomalacia. It was argued that this study could support a hypothesis that some cases of primary basilar impression of the skull are secondary to bone softening associated with malabsorption in early life, the evidence of which may have disappeared in adult life.

Although secondary basilar impression has been described in rickets and osteomalacia, Hurwitz and Shepherd (1966) argued that basilar impression induced by bone softening in early childhood could persist, yet evidence of more generalized bone involvement could largely disappear or never have been apparent. Therefore, some instances designated as primary basilar impression (a genetically determined craniovertebral deformity) were in reality secondary to bone softening in the first years of life; the anomaly at the craniovertebral junction being a sort of 'localized' rickets. Determination of the incidence of basilar impression in patients with adult coeliac disease might help in testing this hypothesis, for it is likely that in many of these patients enteropathy may have been present sub-clinically since the early years of life (Cooke, Peeney, and Hawkins, 1953).

In the present study the incidence of basilar impression in patients with adult coeliac disease is compared with that in adult patients who had had gastric surgery for peptic ulcer. Bone disease if present after gastric surgery could reasonably be related to metabolic effects of the surgical procedure in adult life and any difference in incidence in basilar impression in the two groups

1 Dr. Hurwitz died on 19 October 1971. might indicate the influence of a malabsorption defect in infancy or childhood.

PATIENTS

Three groups of patients were studied.

GROUP 1 Idiopathic steatorrhoea (probable gluten enteropathy). There were 22 patients, 10 males and 12 females between the ages of 21 and 71 years, in this group (Table 1). The criteria employed in the diagnosis of coeliac disease are described by Banerji and Hurwitz (1971a).

TABLE 1

AGE AND SEX OF PATIENTS WITH IDIOPATHIC STEATORRHOEA

\begin{tabular}{lccc}
\hline Age groups $(y r)$ & Females & Males & Total \\
\hline $20-49$ & $5(2)$ & 5 & 10 \\
$50-71$ & $7(3)$ & $5(2)$ & 12 \\
\hline Total & $12(5)$ & $10(2)$ & 22 \\
\hline
\end{tabular}

Figures in parentheses indicate the number of cases with basilar impression.

GROUP 2 In this group there were 24 patients who had no symptoms of diarrhoea before gastric surgery. The age and sex distribution is given in Table 2. The interval from surgery varied from four to 18 years and in 19 patients the interval from the time of surgery varied from four to 18 years and in 19 patients the interval from the time of surgery exceeded 10 years. These patients were among 106 92 
TABLE 2

AGE AND SEX OF PATIENTS WHO HAD GASTRIC SURGERY

\begin{tabular}{lccc}
\hline Age groups $(y r)$ & Females & Males & Total \\
\hline $20-49$ & 3 & 6 & 9 \\
$50-71$ & 4 & $11(1)$ & 15 \\
\hline Total & 7 & 17 & 24 \\
\hline
\end{tabular}

Figure in parentheses indicates the number of cases with basilar impression.

examined for evidence of neurological illness after gastric surgery (Banerji and Hurwitz, 1971b). The selection of group 1 and group 2 patients from among those with idiopathic steatorrhoea or who had had gastric surgery was solely the availability of the radiological procedure on the particular day patients were being examined clinically.

GROUP 3 Control subjects. These subjects were patients attending neurological outpatients with symptoms such as backache and sciatica. They were selected to match the age and sex of the patients in groups 1 and 2. They did not complain of headache and did not give a history of malabsorption or gastric surgery. Neurological examination was normal in these 48 cases and their age and sex are given in Table 3.

TABLE 3

AGE AND SEX OF CONTROL SUBJECTS

\begin{tabular}{lccc}
\hline Age groups $(y r)$ & Females & Males & Total \\
\hline $20-49$ & 9 & 10 & 19 \\
$50-71$ & 12 & 17 & 29 \\
\hline Total & 21 & 27 & 48 \\
\hline
\end{tabular}

METHODS

CRANIOMETRIC RADIOGRAPHY Cephalometric or standardized skull radiographs were taken in the present study by a cephalostat designed by Adams and Brown (1966). The patient was seated in an upright position in the dental chair which was raised or lowered to permit comfortable adjustment of the patient's head to the instrument. The ear rods were inserted into the ear holes and fixed firmly so that the under surfaces of the superior borders of the ear holes were resting on the upper sides of the ear rods. The Frankfurt plane (which extends from the upper border of the external auditory canal to the lower orbital border directly below the pupil when the patient is looking forward) was adjusted to the horizontal. The tube was centred to the external auditory meati and the focus-film distance used was 60 in.

MEASUREMENT TO DETECT BASILAR IMPRESSION In the present investigation lateral skull radiograph measurements were used. Evidence of basilar impression was sought by determining the values of Chamberlain's (1939), and McGregor's (1948) measurements and the angle $\beta$ subtended by the plane of the hard palate and the plane of the atlas vertebra (Bull, 1946). The measurements were carried out by placing the radiographs on a horizontal viewing box. The lines required for the measurements were not drawn on the radiographs; instead transparent protractors with parallel lines were used to join the given points. Thus three measurements could be made without bias. The mean of three of each of these measurements was taken.

\section{RESULTS}

In Chamberlain's and McGregor's measures plus $(+)$ indicates the distance of the tip of the odontoid process above the line and negative $(-)$ the distance below the line. The mean of the three measurements and the standard deviation in the three groups are given in Table 4 and the number with basilar impression in the patient groups is given in Table 5.

VARIATION IN CONTROLS The tip of the dens was never found above Chamberlain's line by more than $2 \mathrm{~mm}$ and above the McGregor's line by more than $5 \mathrm{~mm}$. The greatest Bull's angle

TABLE 4

MEASUREMENTS FOR BASILAR IMPRESSION

\begin{tabular}{|c|c|c|c|c|c|}
\hline Groups & $\begin{array}{l}\text { No. of } \\
\text { cases }\end{array}$ & & $\begin{array}{l}\text { Chamberlain's } \\
\text { measure (mm) }\end{array}$ & $\begin{array}{l}\text { McGregor's } \\
\text { measure }(\mathrm{mm})\end{array}$ & $\begin{array}{l}\text { Bull's angle } \\
\text { (in degrces) }\end{array}$ \\
\hline Adult coeliac disease & 22 & $\begin{array}{l}\text { Variation } \\
\text { Mean } \\
\text { SD }\end{array}$ & $\begin{array}{l}-4 \cdot 0-7.0 \\
+0.90 \\
\quad 3.15\end{array}$ & $\begin{aligned}-2 \cdot 0-+11 \cdot 0 \\
+3 \cdot 68 \\
\quad 3 \cdot 57\end{aligned}$ & $\begin{array}{l}10 \cdot 0-38 \cdot 0 \\
19 \cdot 90 \\
7 \cdot 21\end{array}$ \\
\hline Patients after gastric surgery & 24 & $\begin{array}{l}\text { Variation } \\
\text { Mean } \\
\text { SD }\end{array}$ & $\begin{array}{l}-6 \cdot 0-+4 \cdot 0 \\
-1 \cdot 35 \\
2 \cdot 50\end{array}$ & $\begin{array}{l}-3 \cdot 0-+7 \cdot 5 \\
+1 \cdot 06 \\
\quad 2 \cdot 48\end{array}$ & $\begin{array}{c}4 \cdot 5-23 \cdot 0 \\
11.97 \\
5.08\end{array}$ \\
\hline Control & 46 & $\begin{array}{l}\text { Variation } \\
\text { Mean } \\
\text { SD }\end{array}$ & $\begin{array}{l}-9 \cdot 0-+2 \cdot 0 \\
-2 \cdot 4 \\
2 \cdot 4\end{array}$ & $\begin{array}{l}-6 \cdot 5-+5 \cdot 0 \\
+0 \cdot 1 \\
\quad 2 \cdot 5\end{array}$ & $\begin{array}{r}-3-18 \\
10 \cdot 29 \\
4 \cdot 67\end{array}$ \\
\hline
\end{tabular}

Minus or plus indicates that the tip of the odontoid process was below or above the Chamberlain's or McGregor's line. 
TABLE 5

NUMBER OF PATIENTS WITH ABNORMAL SKULL MEASUREMENTS

\begin{tabular}{lccc}
\hline Measurements & Control & \multicolumn{2}{c}{$\begin{array}{c}\text { Number with abnormal } \\
\text { measurements }\end{array}$} \\
\cline { 3 - 4 } & Mean+2SD & $\begin{array}{c}\text { Idiopathic } \\
\text { steatorrhoea }\end{array}$ & $\begin{array}{c}\text { After } \\
\text { gastric } \\
\text { surgery }\end{array}$ \\
\hline $\begin{array}{c}\text { Chamberlain's } \\
\text { measure }\end{array}$ & $+2 \cdot 4$ & $7(7)$ & $2(1)$ \\
$\begin{array}{c}\text { McGregor's } \\
\text { measure }\end{array}$ & $+5 \cdot 1$ & $7(7)$ & $2(1)$ \\
$\begin{array}{c}\text { Bull's angle } \\
\text { surn }\end{array}$ & $19 \cdot 7$ & $11(7)$ & $2(1)$ \\
\hline
\end{tabular}

The mean value of control plus $2 \mathrm{SD}$ is taken as highest value of normal. Figures in parentheses indicate the number of patients in whom all values were abnormal.

observed was $18^{\circ}$ and the lowest was $-3^{\circ}$. There was good correlation among the three measurements between Bull's angle and McGregor's measure $(P<0.01)$, between Bull's angle and Chamberlain's measure $(P<0.05>0.02)$, and between McGregor's measure and Chamberlain's measure $(P<0.01)$. For each of the three measurements a value greater than the mean plus two standard deviations was taken as abnormal and suggesting basilar impression.

VARIATION IN MALABSORPTION SYNDROME There were seven patients $(31.5 \%)$ in which the distance of the tip of the odontoid process was greater than $2.4 \mathrm{~mm}$ above Chamberlain's line and the greatest distance observed was $+7 \mathrm{~mm}$. The tip of the dens was more than $5.1 \mathrm{~mm}$ above McGregor's line in seven cases. Bull's angle was greater than $19.5^{\circ}$ in 12 patients. All three measurements were abnormal in seven cases and Table 1 indicates that these were distributed in the younger and older age groups. The correlation of the different measurements with each other was significant $(\mathrm{P}<0.001)$.

VARIATION IN PATIENTS AFTER GASTRIC SURGERY In two patients Chamberlain's measure was more than $+2.4 \mathrm{~mm}$ and McGregor's measure was more than $+5.1 \mathrm{~mm}$ in two patients. Bull's angle was more than $19.5^{\circ}$ in two patients. All three measurements were abnormal in only one patient who was an elderly man.

COMPARISON OF MEASUREMENTS IN THE THREE GROUPS There was a significant difference $(P<0.001)$ between the groups. Chamberlain's and McGregor's measurements and Bull's angle in the malabsorption group was significantly $(\mathrm{P}<0.001)$ higher than that in the control and the gastric surgery groups. The mean measurements in patients after gastric surgery were not significantly higher than in controls.

Relationship between osteomalacia and basilar impression in patients Osteomalacia was considered present if the serum calcium and/or phosphorus was low and the alkaline phosphatase was elevated. The presence of Looser's zones in the pelvic and femoral bones was accepted as radiological evidence of osteomalacia. Biochemical data were available on every patient in the two patient groups; the majority had had a pelvis radiograph but none had had bone biopsy or measurement of bone indices which might confirm demineralization. Table 6 shows that the occurrence of basilar impression

TABLE 6

RELATIONSHIP BETWEEN BASILAR IMPRESSION, PRESENT OSTEOMALACIA, AND RICKETS

\begin{tabular}{|c|c|c|c|c|c|}
\hline \multirow[t]{2}{*}{ Groups } & \multicolumn{3}{|c|}{ Evidence of osteomalacia } & \multicolumn{2}{|c|}{ Rickets } \\
\hline & $\begin{array}{l}\text { Bio- } \\
\text { chemical } \\
\text { only }\end{array}$ & $\begin{array}{l}\text { Radio- } \\
\text { logy of } \\
\text { pelvis } \\
\text { and/or } \\
\text { femur }\end{array}$ & Absent & Present & Absent \\
\hline $\begin{array}{l}\text { Idiopathic } \\
\text { steatorrhoea }\end{array}$ & $9(1)$ & $6(3)$ & $7(3)$ & $5(4)$ & 17 (3) \\
\hline $\begin{array}{l}\text { Patients after } \\
\text { gastric surgery }\end{array}$ & $5(0)$ & $3(1)$ & $16(0)$ & 0 & 24 (1) \\
\hline
\end{tabular}

Figures in parentheses indicate the number of cases with basilar? impression.

in the patient was not directly related to present evidence of osteomalacia. There was also no relationship to the presence or absence of signs of rickets.

Basilar impression and neurological signs Two patients with malabsorption syndrome with abnormal measurements suggesting basilar impression had abnormal neurological signs-for example, pyramidal tract and posterior column signs (Banerji and Hurwitz, 1971a). One of these patients had generalized bone disease and rickets but the other was of normal stature and had normal bone structure.

The patient in the gastric surgery group with basilar impression had no abnormal neurological signs.

\section{DISCUSSION}

The values found in 'normal subjects' in the present series of measurements used in assessing 
the presence or absence of basilar impression differ from those obtained by other workers (Table 7). The difference can be explained by the variability of the focus-film-distance (ffd) in other series. The ffd was kept constant at

\section{TABLE 7}

MEASUREMENTS FOR BASILAR INVAGINATION IN DIFFERENT SERIES

\begin{tabular}{|c|c|c|c|c|}
\hline Measure & Authors & $\begin{array}{l}\text { Number } \\
\text { in } \\
\text { sample }\end{array}$ & $\begin{array}{l}\text { Mean } \\
(\mathrm{mm})\end{array}$ & $\begin{array}{l}\text { Standard } \\
\text { deviation } \\
\quad(\mathrm{mm})\end{array}$ \\
\hline $\begin{array}{l}\text { Chamber- } \\
\text { lain's }\end{array}$ & $\begin{array}{l}\text { Saunders (1943) } \\
\text { Poppell, Jacobsen, } \\
\text { Duff, and } \\
\text { Gottlieb (1953) } \\
\text { Bull et al. (1955) } \\
\text { Present series }\end{array}$ & $\begin{array}{l}100 \\
102\end{array}$ & $\begin{array}{r}-0.94 \\
+0.06\end{array}$ & $\begin{array}{l}3 \cdot 6 \\
3 \cdot 3\end{array}$ \\
\hline McGregor's & $\begin{array}{l}\text { McGregor (1948) } \\
\text { Bull et al. (1955) } \\
\text { Present series }\end{array}$ & $\begin{array}{r}203 \\
120 \\
48\end{array}$ & $\begin{array}{l}-1.32 \\
-0.39 \\
+0.12\end{array}$ & $\begin{array}{l}2 \cdot 62 \\
3 \cdot 02 \\
3 \cdot 1\end{array}$ \\
\hline Bull's angle & $\begin{array}{l}\text { Bull et al. (1955) } \\
\text { Present series }\end{array}$ & $\begin{array}{r}120 \\
48\end{array}$ & $\begin{array}{r}0 \cdot 58 \\
10 \cdot 54\end{array}$ & $\begin{array}{l}4 \cdot 0 \\
4 \cdot 74\end{array}$ \\
\hline
\end{tabular}

60 in. in the present series whereas in others it was probably variable which would be important when dealing with a small measurement difference. Racial differences may be responsible to some extent in the series of McGregor (1948) who studied African Bantus.

Another important cause of discrepancy in 'normal' values, especially for Bull's angle, is the method of positioning patients during radiography. In the present series all radiographs were taken in an upright position with the head in a true lateral position. Anteroposterior radiograph measurements were not taken because the use of tomography is frequently involved.

Only two patients who had basilar impression developed symptoms and signs of a neurological lesion. Bull, Nixon, and Pratt (1955), and Spillane, Pallis, and Jones (1957) have also observed that the majority of cases with basilar impression do not have neurological symptoms or signs.

Many authors believe that adult gluten enteropathy is a continuation of childhood coeliac disease. Dundon, Dwyer, and Lomas (1963) and Tempany (1969) have drawn attention to the high incidence in Ireland of coeliac disease arising in the first year of life. Some patients in the present study developed signs of rickets in childhood and the majority were short in stature but in none had a diagnosis of coeliac disease been made before adult life. In the present series there were patients with basilar impression and with malabsorption who had no other skeletal deformities and in whom there was no current evidence of osteomalacia. The finding of an increased incidence of basilar impression in patients with adult coeliac disease but not after gastric surgery, irrespective of other evidence of rickets and of present osteomalacia, supports the view of Hurwitz and Shepherd (1966) that localized rickets during the critical period of the first two years of life (when there are unique bone stresses at the craniovertebral junction) leads to the development of basilar impression which may manifest itself clinically without other bone changes in later life. In the present series there is also some suggestion that female hormonal status and senile osteoporosis may be additional factors. Further one might speculate that some patients diagnosed as having primary basilar impression may have had intestinal malabsorption in early life which disappeared with maturity.

We are grateful for Dr. Philip Adams of the Dental Hospital, Royal Victoria Hospital, and the Queen's University for kindly allowing us to use his cephalostat and for his advice. N.K.B. was holding a fellowship awarded by the Royal Victoria Hospital, Belfast, when this work was undertaken.

\section{REFERENCES}

Adams, C. P., and Brown, W. A. B. (1966). The Adams cephalostat. Dental Practitioner, 17, 75-76.

Banerji, N. K., and Hurwitz, L. J. (1971a). Neurological manifestations in adult steatorrhoea (probable gluten enteropathy). Journal of Neurological Sciences, 14, 125141.

Banerji, N. K., and Hurwitz, L. J. (1971b). Nervous system manifestations after gastric surgery. Acta Neurologica Scandinavica, 47, 485-513.

Bull, J. W. D. (1946). Paget's disease of the skull with platybasia. Proceedings of the Royal Society of Medicine, 40, 85-86

Bull, J. W. D., Nixon, W. L. B., and Pratt, R. T. C. (1955). The radiological criteria and familial occurrence of primary basilar impression. Erain, 78, 229-247.

Chamberlain, W. E. (1939). Basilar impression (platybasia). A bizarre developmental anomaly of the occipital bone and upper cervical spine with striking and misleading neurologic manifestations. Yale Journal of Biology and Medicine, 11, 487-496.

Cooke, W. T., Peeney, A. L. P., and Hawkins, C. F. (1953). Symptoms, signs, and diagnostic features of idiopathic steatorrhoea. Quarterly Journal of Medicine, 22, 59-77.

Dundon, S., Dwyer, W. A. K., and Lomas, T. (1963). Coeliac disease in early infancy. Journal of the Irish Medical Association, 53, 112-115.

Hurwitz, L. J., and Shepherd, W. H. T. (1966). Basilar impression and disordered metabolism of bone. Brain, 89 . 223-234. 
McGregor, M. (1948). The significance of certain measurements of the skull in the diagnosis of basilar impression. British Journal of Radiology, 21, 171-181.

Poppel, M. H., Jacobson, H. G., Duff, B. K., and Gottlieb, C. (1953). Basilar impression and platybasia in Paget's disease. Radiology, 61, 639-644.
Saunders, W. W. (1943). Basilar impression: the position of the normal odontoid. Radiology, 41, 589-590.

Spillane, J. D., Pallis, C., and Jones, A. M. (1957). Developmental abnormalities in the region of the foramen magnum. Brain, 80, 11-48.

Tempany, E. Personal communication in McNicholl, B. (1970). Childhood coeliac disease. Journal of the Irish Medical Association, 63, 1-7. 